\title{
Sarkopenik Olgu: Beslenme Destek Tedavisinin İzlemi
}

\section{A Case with Sarcopenia: Monitoring of the Nutritional Support Therapy}

\section{Kadriye Toprak ${ }^{1}$, Jülide Ergil ${ }^{2}$}

Geliş tarihi/Received: 05.12.2020 • Kabul tarihi/Accepted: 12.03.2021

\section{ÖZET}

Sarkopeni, kas yapısında olumsuz değişikliklerin meydana gelmesiyle gelişen, genellikle ileri yaş grubunda yaygın olmakla beraber yaşamın erken dönemlerinde de görülebilen bir kas hastalığıdır. Dünyada olduğu gibi Türkiye'de de görülme durumu yaygındır. Sarkopeni, tedavi edilmediği takdirde çeşitli bireysel, sosyal ve ekonomik yükler oluşturmaktadır. Bu nedenle erken tanı ve gerekli tedavi önem arz etmektedir. Beslenme tedavisi, sarkopeni tedavisinin önemli bileşenlerinden biridir. Bireylerin beslenme durumunun düzenlenmesi sarkopeniyi önleme, olumsuz sonuçlarını engelleme veya geciktirme açısından önemli katkılar sağlamaktadır. Özellikle diyet ile besin alımının yetersiz olduğu durumlarda beslenme destek tedavisinin klinik sonuçlar üzerine olumlu etkisi olduğu bilinmektedir. Bu makalede, sarkopenik bir olguda beslenme destek tedavisi ve izlemi tartışılmıştır.

Anahtar kelimeler: Sarkopeni, beslenme destek tedavisi, lösin, hidroksimetil bütirat

\section{ABSTRACT}

Sarcopenia is a muscle disease rooted in adverse muscle changes in muscle structure and is generally seen in the elderly, but also seen in the early stages of life. It is a common condition seen in Turkey like all over the world. If it is not treated, creates various individual, social and economic burdens. Therefore, early diagnosis and treatment are important. Nutritional therapy is an important component of sarcopenia treatment. Regulation of the nutritional status of individuals makes important contributions in terms of preventing sarcopenia or delaying its negative consequences. It is known that nutritional support therapy has positive effect on clinical outcomes, especially in cases where dietary intake is sufficient. In this article, nutritional support treatment and follow-up in a sarcopenic case was discussed.

Keywords: Sarcopenia, nutritional support therapy, leucine, hydroxymethyl butyrate

1. İletişim/Correspondence: Sağlık Bilimleri Üniversitesi Dışkapı Yıldırım Beyazıt Eğitim Ve Araştırma Hastanesi Klinik Nütrisyon Ünitesi, Ankara, Türkiye E-posta: kadriye.eken.toprak@gmail.com • ๑ https://orcid.org/0000-0001-8706-8689
2. Sağlık Bilimleri Üniversitesi Dışkapı Ylldırım Beyazıt Eğitim Ve Araştırma Hastanesi Anestezi ve Reanimasyon Kliniği, Ankara, Türkiye

๑ $\mathrm{https://0rcid.org/0000-0002-4580-7866}$ 


\section{GíRiş}

Yunanca bir terim olan sarkopeni, "sarks (kas)" ve “penia (kayıp)" sözcüklerinden oluşmakta ve kas kaybı anlamına gelmektedir (1). Son yıllarda sarkopenin sadece kas kütlesi kaybı olmadığı, sarkopeni tanısında düşük kas gücünün, düşük kas kütlesine göre daha belirleyici rol oynadığı belirtilmektedir $(1,2)$. Avrupa Yaşlılarda Sarkopeni Çalışma Grubu (European Working Group on Sarcopenia in Older PeopleEWGSOP)'nun 2019 yılında yayımladığı ikinci ortak görüş raporunda sarkopeni, kas yapısında olumsuz değişikliklerin meydana gelmesiyle gelişen bir kas hastalığı olarak tanımlanmıştır. Genellikle ileri yaş grubunda yaygın olmakla beraber yaşamın erken dönemlerinde de görülebilmektedir (2).

Sarkopeni pek çok farklı nedenle ortaya çlkabilmektedir ve primer ve sekonder olmak üzere iki kategoride sinıflandırılmaktadır (1). Primer sarkopeni; yaş dışında bir etken olmadan ortaya çıkan durum iken sekonder sarkopeni; hastalık, malnütrisyon, sedanter yaşam gibi nedenlere bağlı gelişen sarkopeni durumu olarak belirtilmektedir (3). Dünyada olduğu gibi Türkiye'de de sarkopeni görülme durumu yaygındır. Türkiye'de huzurevlerinde yaşayan bireylerde sarkopeni prevalansı \%68 olarak bulunmuştur (4). Sarkopeni tedavi edilmediğinde çeşitli hastalıklara neden olabilmekte, bireylerin yaşam kalitesini düşürmekte ve hatta ölümle sonuçlanabilmektedir (2,5). Bununla birlikte sarkopeninin sağlık harcamalarını da arttırdığı belirtilmektedir (6). Bu nedenle sarkopenide erken tanı ve tedavi de önemlidir. EWGSOP-2 sarkopeni taramasında "Basit Sarkopeni Sorgulama Formu” (A Simple Questionnaire to Rapidly Diagnose SarcopeniaSARC-F)'nun kullanılmasını önermiştir (2). SARC-F; güç, yürümede kullanılan yardımcı materyal, sandalyeden kalkma, merdiven çıkma, düşme ile ilgili beş soru içeren, her soru için 0-2 puan arası skorlaması olan ve dördün üzerinde skor saptanan bireyleri sarkopeni için ileri değerlendirmeye yönlendiren, basit ve kolay uygulanabilir bir tarama testidir (2). EWGSOP-2 sarkopeni riski saptanan bireylerde bir ileri basamak olarak kas gücü ölçümü yapılmasını da önermektedir (2). Klinik uygulamalarda, kas gücü ölçümü için basit, ucuz ve etkin bir yöntem olan el dinamometresi ile el kavrama gücü ölçümü sıklıkla tercih edilen bir yöntemdir (7). Erkekler için <27 kg, kadınlar için < $16 \mathrm{~kg}$ düşük kas gücünün göstergesidir (2).

Beslenme destek tedavisi de sarkopeniyi önleme, olumsuz sonuçlarını engelleme veya geciktirme açısından önemli bir etmendir (4). Beslenme desteğinde yeterli enerji alımının yanında yeterli protein alımının sağlanması gerekmektedir. Özellikle yaşlı bireylerde kas kütlesinin ve işlevinin korunması için günde 1.0-1.2 g/kg protein tüketimi önerilmekte, dallı zincirli aminoasit (DZAA) olan lösinin kas kütlesi ve işlevini geliştirmeye yardımcı olabileceği belirtilmektedir (8). Bunun yanı sıra, yeterli vitamin ve mineral alımı ile birlikte kas protein metabolizmasına pozitif etkileri olan D vitamini takviyesi de sarkopeni tedavisinin önemli bir parçasını oluşturmaktadır $(2,9)$.

\section{OLGU SUNUMU}

Olgu 67 yaşında, erkek hastadır. Bilinen ek hastalık veya ilaç kullanımı olmayan hasta, bir yıl önce ses kısıklığı ve öksürükle birlikte ağızdan 1-2 damla kan gelme şikayeti ile Kulak Burun Boğaz Hastalıkları polikliniğine başvurmuştur. Boyun tomografisinde kitle saptanan hasta ileri tetkik için göğüs hastalıkları kliniğine yönlendirilmiştir. Burada yapılan biyopsi sonucunda hasta küçük hücreli akciğer kanseri tanısı almıştır. Hastaya toplam $6 \mathrm{doz}$ sisplatin + etoposid verilmesi planlanmıştır. Hastanın almış olduğu bu kemoterapiden 4 ay sonrasinda istenen karşılaştırmalı tomografisinde sol hemitoraksta plevral yüzlerde belirgin artış gösteren metastatik nodüler kalınlaşmalar ve artış gösteren plevral efüzyon saptanmıştır. Bu bulgular progresyon lehine değerlendirilmiş ve hastaya ikinci basamak topotekan tedavisi planlanmıştır. Hastanın kemoterapi öncesi genel sağlık durumunun düşük olması nedeniyle hastaneye yatışı yapılmış, yapılan fiziki muayenede 
bilinci açık, oryante ve koopere olduğu görülmüştür. Hastanın kan basıncı 120/80 mmHg, solunum sayısı 14/ $\mathrm{dk}$, vücut ısısı $36.8^{\circ} \mathrm{C}$ ve nabız $89 / \mathrm{dk}$ olarak ölçülmüş, vücut ağırlığı $51 \mathrm{~kg}$, boy uzunluğu $165 \mathrm{~cm}$ ve beden kütle indeksi (BKI) 18.7 kg/m2 olarak kaydedilmiştir. Hastanın oral besin tüketiminin yetersiz olması nedeniyle tıbbi beslenme tedavisinin yapılması için klinik nütrisyon ünitesinden konsültasyon istenmiştir.

Klinik nütrisyon ünitesinde görevli diyetisyen tarafindan hastanın vücut ağırlığı ve boy uzunluğu ölçümü yapılmıştır. Vücut ağırlığı ölçümü 0.1 kg’a duyarlı Seca 769 marka dijital terazi ile mümkün olduğunca az ve ince kıyafetle, ayakkabısız olarak, boy uzunluğu ise teraziye bağll boy uzunluk cetveli ile ayaklar yan yana ve baş frankfurt düzleminde (göz üçgeni ve kulak kepçesi üstü aynı hizada yere paralel) olacak şekilde ölçülmüştür (10). Hastanın malnütrisyon riski Nütrisyonel Risk Taraması (Nutritional Risk Screening-NRS-2002) aracı ile değerlendirilmiştir. NRS-2002, hastanede yatan bireylerde beslenme durumunu saptama amaciyla geliştirilmiş, iki bölümden oluşan ve puanlama yapılan bir tarama aracıdır. NRS-2002 puanının 3’ün üzerinde olması durumunda hastanın nütrisyon riski altında olduğu ve bir nütrisyon planının yapılması gerektiği belirtilmektedir (11). Olgunun NRS-2002 skoru 4 olarak saptanmış ve bu sonuca göre hastaya beslenme desteği yapılmasına karar verilmiştir. Olgunun geriye dönük 24 saatlik besin tüketim kaydına göre günlük 535 kkal enerji (günlük enerji ihtiyacının yaklaşık \%30’u) ve 18 g protein aldığı saptanmış ve hasta oral yolla beslenebildiği için oral enteral beslenme desteği planlanmıştır. Olgunun tanısı göz önünde bulundurularak, günlük enerji ve protein gereksinimi, Avrupa Beslenme ve Metabolizma Derneği (European Society for Clinical Nutrition and Metabolism-ESPEN)'nin 2017 yllında yayımlanan rehberinde kanser hastaları için önerilen miktarlara (25-30 kkal/kg/gün enerji ve 1-1.5 g/kg/gün protein) göre hesaplanmıştır (12). Buna göre hastanın günlük enerji gereksinimi 1625-1950 kkal, protein gereksinimi 51-76.5 g olarak hesaplanmıştır. Beslenme desteğinde öncelikli hedefin yeterli protein alımının sağlanması olduğundan ve hastanın hastanede verilen rejim 3 (R3) normal diyetinden sağladığ 1 protein miktarının çok düşük olmasından dolayı, günlük protein gereksiniminin büyük bir kısmının beslenme destek ürünlerinden karşlanacak şekilde bir beslenme programı oluşturulmuştur. Hastanın alması gereken protein miktarının 1.5-2.0 g/kg/gün ve enerji miktarının 25-30 kkal/kg/gün aralıklarında olması hedeflenmiş ve hastaya R3 normal diyetine ek olarak iki farklı oral beslenme destek ürününün kombine kullanımı önerilmiştir. Ürünlerden birincisi kanser ve kaşekside önerilen 2 x 200 mL (1 adet içeriği: 300 kkal ve $20 \mathrm{~g}$ protein) ikincisi ise düşük hacimde yüksek enerji alımını sağlayan 2 x 125 mL (1 adet içeriği: $300 \mathrm{kkal}$ ve $13 \mathrm{~g}$ protein) beslenme destek ürünüdür. Hastaya ürünlerin kullanımı ve saklama koşulları ile ilgili gerekli bilgiler verilmiştir.

Kanser tedavisi ile izlenen hastada, beslenme tedavisi başlangıcından beş gün sonra klinikteki sorumlu hekiminin kararı ile sarkopeni varlığı araştırılmıştır. EWGSOP-2'nin önerdiği algoritma dikkate alınarak, hastaya SARC-F uygulanmış ve TKK 5401 dijital el dinamometresi kullanılarak hastanın el kavrama gücü ölçülmüştür. Ölçümler, hasta ayakta, dirsek ve el bileği tam ekstansiyonda iken yapılmış, baskın ve baskın olmayan ellerde 5'er saniye aralıkla 3 kez ölçüm yapılmış, değerler kilogram cinsinden kaydedilerek, ortalamaları alınmıştır (10). SARC-F skoru 5 olarak saptanan hastanın, el kavrama gücü düşük (24.9 kg) bulunmuştur. EWGSOP-2'nin belirlediği referans aralıklarına göre değerlendirilen hastada olası sarkopeni durumu saptanmış ve hastanın beslenme tedavisi sarkopeni önerileri doğrultusunda yeniden gözden geçirilmiştir. Diyet ile besin alımının bir miktar arttığı gözlenen hastanın besin tüketimi tekrar değerlendirilmiştir. Alması hedeflenen 25-30 kkal/kg enerji ve 1.5-2.0 g/kg/gün proteine ulaşabilmesi için almakta olduğu R3 diyetine ek olarak 1 x 125 mL (1 adet içeriği $300 \mathrm{kkal}, 13 \mathrm{~g}$ protein) ile 2 x $220 \mathrm{~mL}$ [1 adet içeriği $330 \mathrm{kkal}, 20 \mathrm{~g}$ protein, 1,5 g kalsiyum betahidroksi-beta-metil bütirat (CaHMB), 500 IU vitamin D] olmak üzere iki farklı oral beslenme destek ürünü önerilmiştir. 
Hastanın günlük aldığı enerji ve protein miktarları düzenli olarak takip edilmiştir. Sarkopeniye yönelik beslenme destek tedavisinin başlangıcından, hastanın taburculuğuna kadar geçen süreçte günlere göre önerilen ve tüketilen enerji ve protein miktarları Grafik 1 ve Grafik 2'de verilmiştir. Hastanın en son düzenlenmiş olan beslenme tedavisinin 9. günü R3 diyeti alım durumunun iyiye gitmesi göz önünde bulundurularak beslenme desteğine 2 x $220 \mathrm{~mL}$ (1 adet içeriği $330 \mathrm{kkal}, 20 \mathrm{~g}$ protein, $1.5 \mathrm{~g}$ CaHMB, 500 IU vitamin D) ve 3 x 2 ölçek protein tozu (1 ölçek 2.2 g protein) olmak üzere iki ürün ile devam edilmiştir. Hasta, sarkopeniye yönelik beslenme destek tedavisinin başlangıcından iki hafta sonra, hastanede verilen beslenme destek tedavisini devam ettirme önerisiyle birlikte taburcu edilmiş ve iki hafta sonra kontrol randevusunda klinik nütrisyon ünitesine de kontrole çağırılmıştır. Hasta taburculuk sonrası evde devam eden beslenme destek tedavisine uyduğunu belirtmiş, bu süreçte kaydedilen besin tüketim kayıtları incelenmiştir. Yapılan son değerlendirmelerde, hastanın vücut ağırlığı ve el kavrama gücü ölçümlerinde artış gözlenmiştir. Hastaya verilen beslenme destek tedavisi öncesinde

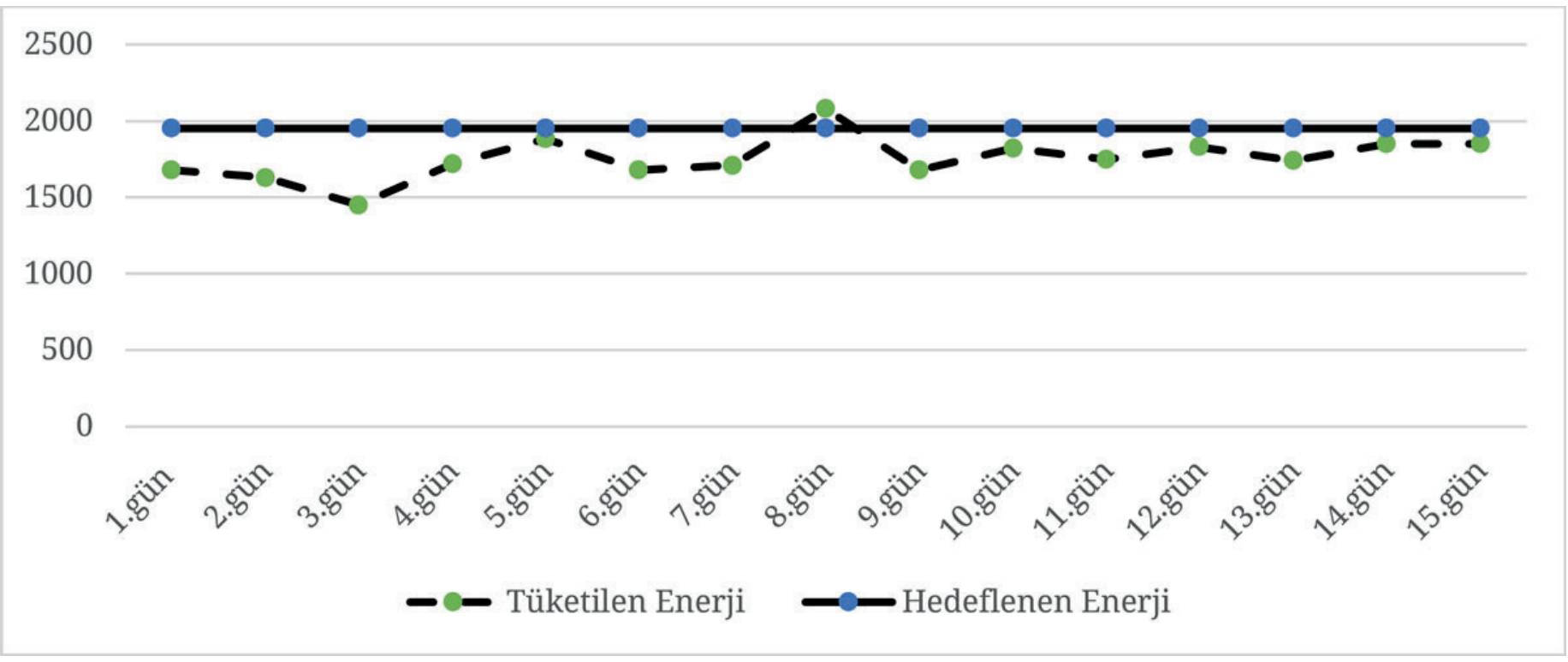

Grafik 1. Günlere Göre Hedeflenen ve Tüketilen Enerji Miktarları (kkal)

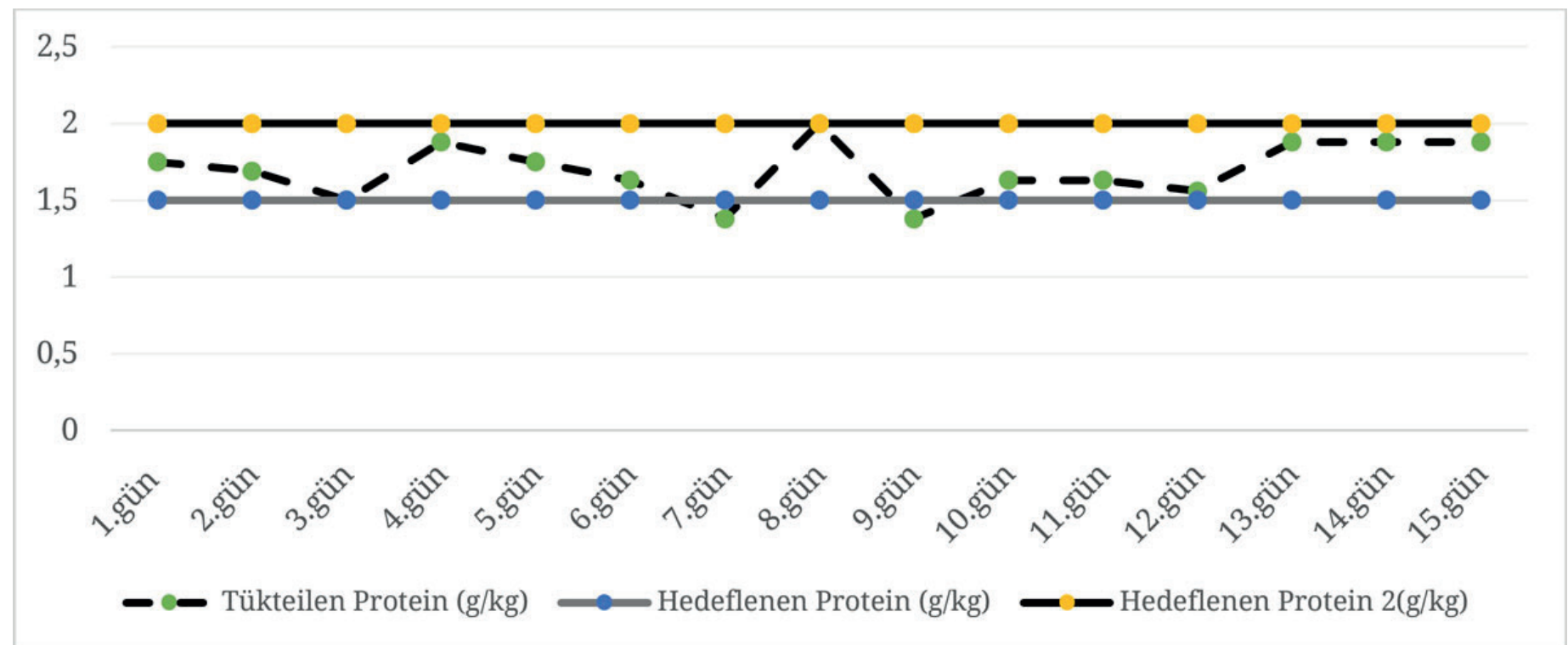

Grafik 2. Günlere Göre Hedeflenen ve Tüketilen Protein Miktarları (g/kg) 
ve sonrasındaki vücut ağırlığı ve el kavrama gücü ölçümleri Tablo 1'de yer almaktadır.

Tablo 1. Beslenme Destek Tedavisi Öncesinde ve Sonrasındaki Vücut Ağırlığı ve El Kavrama Gücü Ölçümleri

\begin{tabular}{lcc}
\hline & $\begin{array}{c}\text { Tedavi } \\
\text { Başlangıcı }\end{array}$ & $\begin{array}{c}\text { Taburculuk Sonrası } \\
\text { Kontrol }\end{array}$ \\
\hline Vücut ağırlığı (kg) & 51.0 & 51.9 \\
El kavrama gücü $(\mathrm{kg})$ & 24.9 & 25.4 \\
\hline
\end{tabular}

$\mathrm{Bu}$ olgunun yazımı için hastadan yazılı onam alınmıştır.

\section{TARTIŞMA}

$\mathrm{Bu}$ olgu çalışmasında, akciğer kanseri ile takip edilen bir hastada, hastalığa bağlı gelişen sarkopeni durumunda verilen beslenme destek tedavisi ve bu tedavinin etkinliği ele alınmıştır.

Herhangi bir hastalığa bağlı gelişen sarkopeni durumu sekonder sarkopeni olarak adlandırılmakta ve bu durum kanser hastalarında sıklıkla görülmektedir (3). $\mathrm{Bu}$ olgu, klinik nütrisyon ünitesinden konsültasyon istendiğinde henüz sarkopeni durumu sorgulanmamış bir akciğer kanser hastasıdır. Bu nedenle beslenme destek tedavisinde kanser hastalarına yönelik öneriler dikkate alınmıştır. Yetersiz beslenme ve kaşeksi kanser hastalarında sıklıkla görülmektedir ve kötü prognozun göstergeleridir (13). Hastalığın kendisinden veya tedaviden kaynaklanan sorunlar nedeniyle günlük enerji ve besin öğeleri gereksinimleri karşılanmayabilir. Bu nedenle kanserde beslenme destek tedavisinin planlanması önemlidir (12).

Besin tüketimleri azalmış bireylerde kansere bağlı gelişen katabolizmayı azaltmak veya immünolojik durumu iyileştirmek için beslenme destek ürünleri önerilmektedir $(12,13)$. Bu olgu için enerji ve protein gereksinimi ESPEN'in 2017 yllında yayımladığ kanser hastalarına yönelik önerileri içeren kılavuz doğrultusunda yapılmıştır (12). Enerji gereksinimi 25-30 kkal/kg/gün; protein gereksinimi 1-1.5 g/kg/gün olacak şekilde hesaplanmıştır. Hastanın 24 saatlik hatırlatma yöntemi ile besin tüketim kaydı alınmış, gereksiniminin geri kalan kısmı da oral beslenme destek ürünleri ile karşılanmaya çalışılmıştır. Özellikle hedeflenen protein miktarına ulaşılmasına dikkat edilmiştir.

Beslenme durumu takibinden bir hafta sonra olguda sarkopeni varlığı sorgulanmıştır. Sarkopeni, bireyler ve sağllk sistemi üzerinde büyük bir yük oluşturmaktadır. Bu nedenle erken tanı ve tedavi çok önemlidir. Günümüzde klinik pratikte sarkopeninin hızlı bir şekilde taranması açısından çeşitli tarama araçları ve yöntemler üzerinde çalışılmaktadır (2). EWGSOP çalışma grubunun 2018 yılında geliştirdiği algoritmada olası sarkopeni risk taraması amacıyla ucuz ve kolay bir yöntem olarak SARC-F'in ve kas gücü ölçümünün kullanılması önerilmektedir. Algoritmaya göre yüksek SARC-F skoru ve düşük kas gücü olası ve tedavi gerektiren sarkopeni durumunu göstermektedir (2). Bu olguda SARC-F skoru yüksek, kas gücü ölçümü düşük bulunmuştur. Bu verilere göre olguda sarkopeni mevcudiyeti kabul edilerek, uygulanmakta olan beslenme destek tedavisi yeniden gözden geçirilmiştir.

Sarkopeniye yönelik beslenme tedavisinde yeterli ve dengeli beslenmenin yanında, kas gücü ve işlevinin sağlanması için alınan protein miktarı çok önemlidir. Sağlıklı yaşlı bireylerde kas kütlesinin korunması için gerekli olan protein alımının 1.0-1.2 g/kg/gün olması önerilirken, akut/kronik rahatsızlığı olan (diyalize girmeyen böbrek hastaları hariç) yaşlı bireyler için 1.2-1.5 g/kg/gün, kritik hastalığı olanlar için ise 2.0 $\mathrm{g} / \mathrm{kg} / g u ̈ n$ protein alımı önerilmektedir (8). Bu öneri doğrultusunda olgunun protein gereksiniminin sarkopeni durumu saptandıktan sonra 1.5-2.0 g/ kg/gün aralığında olması hedeflenmiştir. Protein tüketim miktarının yanı sıra, lösin ve glutamin gibi fonksiyonel aminoasitlerin alımı da kaslardaki protein metabolizması için önemlidir (14). Lösinin kaslarda protein sentezini arttırıp, yıkımını azaltarak pozitif protein dengesi sağladığı ve uzun vadede vücut kompozisyonunu olumlu etkilediği belirtilmektedir (15). Sarkopenik bireyler ile yürütülen bir çalışmada, lösin ile zenginleştirilmiş aminoasit takviyesinin bireylerde kas kütlesi ve gücünü arttırdığı saptanmıştır (16). Bununla birlikte 
lösinin aktif bir metaboliti olan beta-hidroksi betametil butirat (HMB)'ın sarkopenide gözlenen kas kütlesi ve gücündeki düşüşler üzerinde olumlu etkileri olduğuna dair artan kanttlar bulunmaktadır $(17,18)$. Din ve ark. (18), yaşlı bireyler ile yürüttükleri çalışmalarında 3 g/gün HMB takviyesinin kas kütle ve gücünü arttırdığını rapor etmişlerdir. HMB’nin, mTOR yolağını uyararak protein sentezini arttırması ve kas proteinlerinin yıkımına neden olan bazı enzim aktivitelerini azaltması kas kütlesi üzerindeki olumlu etkileri için önerilen mekanizmalar arasında yer almaktır (17). Sarkopenide önemi vurgulanan diğer bir besin ögesi D vitaminidir. Birçok çalışmada düşük D vitamini seviyelerinin düşük kas gücü ve işlevi ile ilişkili olduğu gösterilmiş, D vitamini takviyesinin kas kütlesi ve gücü üzerinde olumlu etkileri olduğu saptanmıştır $(9,19)$. Yaşlı bireyler ile yürütülen birçok randomize kontrollü çalışmanın metaanalizinde, günde 800-1000 IU arasında D vitamin takviyesinin kas gücü üzerinde yararlı etkileri olduğu rapor edilmiştir (9). Olguda sarkopeni saptandıktan sonra verilen beslenme destek tedavisi yeniden gözden geçirilmiş, sarkopenide önemi vurgulanan bu besin ögeleri dikkate alınarak, kullanılan ürün değiştirilmiş ve hastaya CaHMB ile D vitamini içeren yüksek proteinli hiperkalorik bir beslenme destek ürünü başlanmıştır. Ürünün içerdiği önemli besin ögelerinin yanında aynı zamanda hiperkalorik olması besin tüketimleri azalan yaşlı bireyleri negatif enerji dengesinden koruyarak, kas yıkımını da engellemesi açısından önemlidir.

Beslenme yetersizliğinde, özellikle hastanede yatan malnütrisyon ve malnütrisyon riski olan hastalarda diyetle besin alımı ve vücut ağırlığını arttırmak, hastalık komplikasyonlarından korunmak için oral beslenme destek ürünlerinin kullanımı önerilmektedir. Uygulanacak olan beslenme destek tedavisi, en az 1 ay boyunca düzenli uygulanmalı ve günde en az $400 \mathrm{kkal}$ enerji ve $30 \mathrm{~g}$ protein sağlayacak şekilde olmalıdır (20). Bu olguda da beslenme destek tedavisi taburculuk sonrası kontrolüne kadar en az 1 ay süresince uygulanmış ve tedavinin hastanın vücut ağırlığı ve kas gücü ölçümlerinde bir artış sağladığı görülmüştür.
Sonuç olarak, hangi nedene bağlı olursa olsun sarkopeni tedavi edilmediğinde çeşitli bireysel, sosyal ve ekonomik yükler oluşturmakta, bu nedenle sarkopenide erken tanı ve gerekli tedavi önem arz etmektedir. Klinik uygulamada sarkopeninin hızlı bir şekilde taranması SARC-F ve kas gücü ölçümü ile kolaylıkla yapılabilmektedir. Beslenme tedavisi sarkopeni tedavisinin önemli bir bileşenidir. Sarkopenik vakalarda beslenme tedavisinde gerekli olan enerji ve besin ögelerinin sağlamasının yanında kas yapımını arttıran fonksiyonel besin ögelerinin tüketimi de sağlanmalıdır. Diyetle alımın yetersiz olduğu durumlarda oral beslenme destek ürünlerinin kullanımı tedavinin başarısı açısından önemlidir.

Çıkar çatışması - Conflict of interest: Yazarlar çıkar çatışması olmadığını beyan ederler. - The authors declare that they have no conflict of interest.

\section{KAYNAKLAR}

1. Cruz-Jentoft AJ, Baeyens JP, Bauer JM, Boirie Y, Cederholm T, Landi F, et al. Sarcopenia: European consensus on definition and diagnosis: Report of the European Working Group on Sarcopenia in older people. Age Ageing. 2010;39(4):412-12.

2. Cruz-Jentoft AJ, Bahat $G$, Bauer J, Boirie $Y$, Bruyère $O$, Cederholm T, et al. Sarcopenia: Revised European consensus on definition and diagnosis. Age Ageing. 2019;48(1):16-15.

3. Peixoto da Silva S, Santos JM, Costa e Silva MP, Gil da Costa RM, Medeiros R. Cancer cachexia and its pathophysiology: Links with sarcopenia, anorexia and asthenia. J Cachexia, Sarcopenia Muscle. 2020;11:619-16.

4. Halil M, Ulger Z, Varlı M, Döventaş A, Oztürk G, Kuyumcu $\mathrm{M}$, et al. Sarcopenia assessment project in the nursing homes in Turkey. Eur J Clin Nutr. 2014;68(6):690-4.

5. Bahat G, Ilhan B. Sarcopenia and the cardiometabolic syndrome: A narrative review. Eur Geriatr Med. 2016;7(3):220-3.

6. Antunes AC, Araújo DA, Veríssimo MT, Amaral TF. Sarcopenia and hospitalisation costs in older adults: A cross-sectional study. Nutr Diet. 2017;74(1):46-5.

7. Rijk JM, Roos PR, Deckx L, Van den Akker M, Buntinx F. Prognostic value of handgrip strength in people aged 60 years and older: a systematic review and meta-analysis. Geriatr Gerontol Int. 2016;16(1):5-15.

8. Bauer J, Biolo G, Cederholm T, Cesari M, Cruz-Jentoft AJ, Morley JE, et al. Evidence-Based Recommendations 
for Optimal Dietary Protein Intake in Older People: A Position Paper from the PROT-AGE Study Group. JAMDA. 2013;14(8):542-17. Muir SW, Montero-Odasso M. Effect of D vitamin supplementation on muscle strength, gait and balance in older adults: a systematic review and meta-analysis. J Am Geriatr Soc. 2011;59:2291-10.

9. Pekcan G, Beslenme durumunun saptanması. Baysal A, Aksoy M, Besler T, Bozkurt N, Keçecioğlu S, Kutluay Merdol T ve ark, editörler, Diyet El Kitabı. 5. Baskı. Ankara: Hatiboğlu Yayınları; 2008. s. 67-75

10. Kondrup J, Rasmussen HH, Hamberg OLE, Stanga Z, \& An ad hoc ESPEN Working Group. Nutritional risk screening (NRS 2002): a new method based on an analysis of controlled clinical trials. Clin Nutr. 2003;22(3):321-15.

11. Arends J, Bachman P, Baracos V, Barthelemy N, Bertz H, Bozzetti F, et al. ESPEN guidelines on nutrition in cancer patients. Clin Nutr. 2017;36(1):11-37

12. Arends J, Bodoky G, Bozzetti F, Fearon K, Muscaritoli M, Selga G, et al. ESPEN guidelines on enteral nutrition: Non-surgical oncology. Clin Nutr. 2006;25(2):245-14.

13. Deutz NE, Bauer JM, Barazzoni R, Biolo G, Boirie Y, BosyWestphal A, et al. Protein intake and exercise for optimal muscle function with aging: recommendations from the ESPEN expert group. Clin Nutr. 2014;33(6):929-7.

14. Rondanelli M, Faliva M, Monteferrario F, Peroni G,
Repaci E, Allieri F, et al. Novel insights on nutrient management of sarcopenia in elderly. Biomed Res Int. 2015;2015:524948.

15. Yoshimura Y, Bise T, Shimazu S, Tanoue M, Tomiako Y, Araki M, et al. Effect of a leucine-enriched amino asit supplement on muscle mass, muscle strength, and physical function in post stroke patients with sarcopenia: A randomized controlled trial. Nutr. 201958:1-6.

16. Holecek M. Beta-hydroxy-beta-methylbutyrate supplementation ond skeletal in healthy and musclewasting conditions. J Cachexia Sarcopenia Muscle. 2017;8(4):529-12.

17. Din USU, Brook MS, Selby A, Quinlan J, Boereboom C, Abdulla $\mathrm{H}$, et al. A double-blind placebo controlled trial into the impacts of HMB supplementation and exercise on free-living muscle protein synthesis, muscle mass and function, in older adults. Clin Nutr. 2019;38(5):20718.

18. Apaydın M, Gencay Can A, Kizilgul M, Beysel S, Kan S, Caliskan M, et al. The effects of single high-dose or daily low-dosage oral colecalciferol treatment on vitamin $\mathrm{D}$ levels and muscle strength in postmenopausal women. BMC Endocrine Disorders. 2018;18(1):1-6.

19. Volkert D, Beck AM, Cederholm T, Cruz-Jentoft A, Goisser S, Hooper L, et al. ESPEN guideline on clinical nutrition and hydration in geriatrics. Clin Nutr. 2019;38(1):10-37. 